\title{
Global Warming Will Aggravate Ozone Pollution in the U.S. Mid-Atlantic
}

\author{
Cristina L. Archer, Joseph F. Brodie, ${ }^{a}$ ANd SARA A. RAUSCHER \\ College of Earth, Ocean, and Environment, University of Delaware, Newark, Delaware
}

(Manuscript received 1 October 2018, in final form 4 March 2019)

\begin{abstract}
The goal of this study is to evaluate the effects of anthropogenic climate change on air quality, in particular on ozone, during the summer in the U.S. mid-Atlantic region. First, we establish a connection between high-ozone (HO) days, defined as those with observed 8-h average ozone concentration greater than 70 parts per billion (ppb), and certain weather patterns, called synoptic types. We identify four summer synoptic types that most often are associated with HO days based on a 30-yr historical period (1986-2015) using NCEP-NCAR reanalysis. Second, we define thresholds for mean near-surface temperature and precipitation that characterize HO days during the four HO synoptic types. Next, we look at climate projections from five models from phase 5 of the Coupled Model Intercomparison Project (CMIP5) for the early and late midcentury (2025-34 and 2045-54) and analyze the frequency of HO days. We find a general increasing trend, weaker in the early midcentury and stronger in the late midcentury, with 2 and 5 extra HO days per year, respectively, from 16 in 2015. These 5 extra days are the result of two processes. On one hand, the four HO synoptic types will increase in frequency, which explains about 1.5-2 extra HO days. The remaining 3-3.5 extra days are explained by the increase in near-surface temperatures during the HO synoptic types. Future air quality regulations, which have been successful in the historical period at reducing ozone concentrations in the mid-Atlantic, may need to become stricter to compensate for the underlying increasing trends from global warming.
\end{abstract}

\section{Introduction}

The most recent report of the Intergovernmental Panel for Climate Change (IPCC) indicates that an average global warming of about $2^{\circ} \mathrm{C}$ is likely by the end of the century, based on medium- to high-emission scenarios (IPCC 2013). Along the U.S. East Coast, the warming is projected to be even stronger with an increase of $2.5^{\circ}-5.5^{\circ} \mathrm{C}$ (Maloney et al. 2014). Heat waves are expected to be more frequent and more intense and to last longer. For example, the number of days above

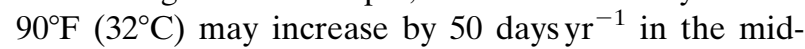
Atlantic region by the middle of the century if $\mathrm{CO}_{2}$ emissions continue on their current trajectory (Melillo et al. 2014). Such increases in extreme temperatures are likely to have a negative impact on public health all along the mid-Atlantic, as high temperatures are associated with increased mortality. This temperature-mortality

\footnotetext{
${ }^{a}$ Current affiliation: Department of Marine and Coastal Sciences, Rutgers, The State University of New Jersey, New Brunswick, New Jersey.
}

Corresponding author: Cristina L. Archer, carcher@udel.edu link appears to be strongest in the eastern United States compared to other parts of the country (Curriero et al. 2002; Anderson and Bell 2009).

Global warming may exacerbate indirect health impacts via near-surface ozone $\left(\mathrm{O}_{3}\right)$ pollution (Monks et al. 2015). Ozone is a summer pollutant, regulated by the U.S. Environmental Protection Agency (EPA), that forms in the atmosphere as a result of photochemical reactions between nitrogen oxides $\left(\mathrm{NO}_{x}\right)$ and volatile organic compounds. Ozone has large negative impacts on health, especially affecting the cardiopulmonary and respiratory systems (EPA 2018b). In Delaware, ozone is the only regulated pollutant that exceeds national and state standards regularly [Delaware Department of Natural Resources and Environmental Control, Division of Air Quality (DNREC-DAQ) 2016], as will be discussed in detail later (section 2a). We focus on Delaware as representative of the mid-Atlantic region because of its central location. Further, since Delaware is a small state, even a few stations can represent ozone conditions over the state well.

Ozone is expected to reach higher concentrations (i.e., increase in intensity) and/or exceed national and state standards more often (i.e., increase in frequency) 
because of climate change via several mechanisms. First, higher temperatures enhance photochemical reactions that form ozone. Second, high-ozone (HO) episodes tend to occur during certain synoptic conditions, such as a high pressure system (e.g., the Bermuda high). These synoptic conditions may occur more often in the future, leading to more frequent $\mathrm{HO}$ events (Shen et al. 2015; Leibensperger et al. 2008). This paper will focus on this second indirect mechanism, that is, changes in the frequency of $\mathrm{HO}$ events in the future caused by changes in synoptic conditions. Since Delaware is a state with low local emissions and its ozone pollution is dominated by transport from upwind states (Moghani et al. 2018), it is a region where ozone tends to be dominated by synoptic, more than local, weather conditions.

How can we make projections of whether or not $\mathrm{HO}$ events may occur more frequently in the future? The most common tool used to create projections of future climate is coupled atmosphere-ocean models, such as the models included in phase 5 of the Coupled Model Intercomparison Project (CMIP5; Taylor et al. 2012). The results of these model simulations form the basis of the papers that are used in the IPCC Assessments, for example, IPCC (2013). However, most models (unless specifically outfitted with complex chemistry models) do not include ozone as a prognostic variable. Therefore, to make projections of how HO days may change in the future, we must relate ozone concentrations to variables that all coupled atmosphere-ocean climate models simulate, like pressure and temperature. Then we can determine how those variables are changing and the implications of their changes on the frequency of $\mathrm{HO}$ days.

Here we make use of CMIP5 simulations to project how the number of HO days may change over the midAtlantic region (and more specifically, Delaware), for two midcentury periods, 2025-34 and 2045-54, and compare this to the frequency of ozone days for the present day (1986-2015). Section 2 gives an overview of the observed and model data sources, while section 3 details the synoptic typing and other criteria used to classify days as "high ozone." Section 4 discusses the results, while section 5 offers conclusions and directions for future research.

\section{Data sources}

\section{a. Delaware ozone data}

The period of interest for this study is 1986-2015. The DNREC DAQ operates a network of air quality stations throughout the state, recording a number of parameters, including ozone. The first three ozone monitoring sites (Claymont, Lums Pond, and Bellefonte) became

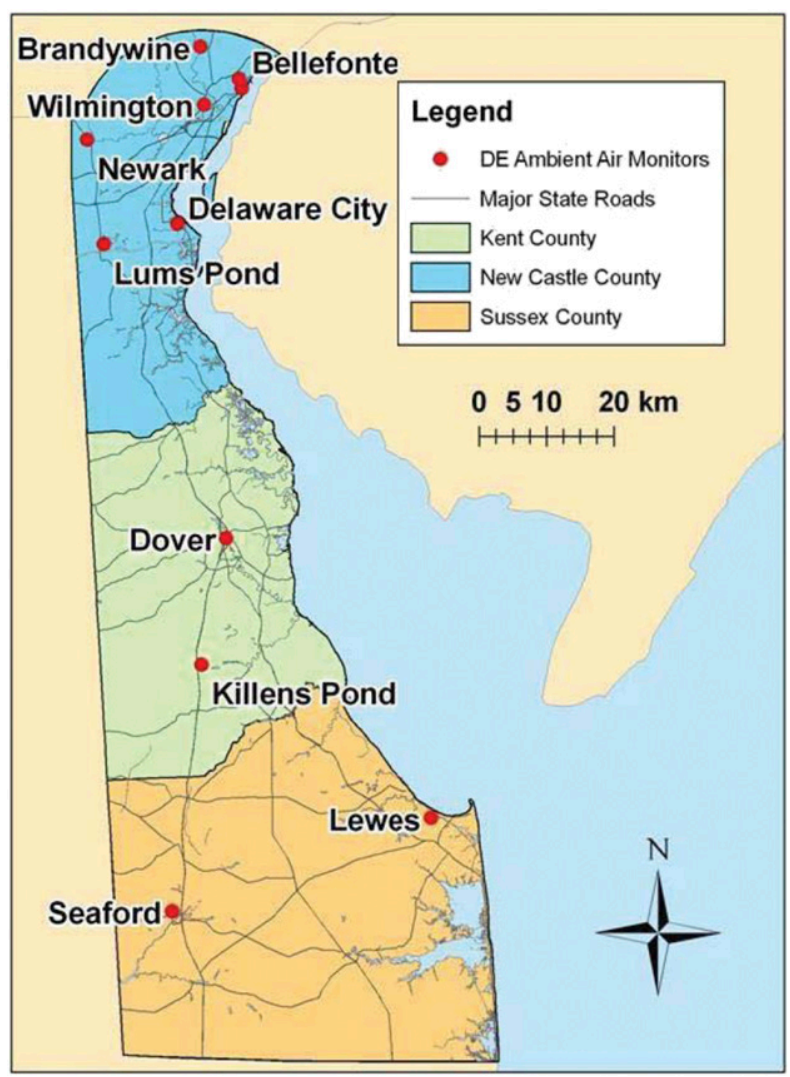

FIG. 1. Map of the air quality monitoring stations in the state of Delaware from DNREC-DAQ (2018). Dover, Delaware City, and Newark do not record ozone.

operational in 1982, with additional stations being added, removed, or replaced since then. Since 2011, there are seven stations that record ozone with 1-h frequency (DNREC-DAQ 2018). The locations of these seven ozone monitoring stations are depicted in Fig. 1 and listed in Table 1. Since Delaware is a small state composed of only three counties, these seven stations provide a reasonable spatial coverage, with two stations in southernmost Sussex County, one station in central Kent County, and four stations in the more heavily populated northernmost New Castle County. These data are archived by DNREC and made available via the U.S. EPA Air Data portal (EPA 2018a).

Even though hourly values are recorded, the daily maximum 8-h average ozone concentration is used in this analysis to represent the daily value of ozone at each station. These 8-h averages have been error checked by DNREC and EPA. For example, an 8-h average is considered valid if at least six of the 8-hourly concentrations for the 8-h period are available and a daily maximum 8-h average ozone concentration is considered valid if valid 8-h averages are available for at least 13 of the 17 consecutive 8 -h periods starting from 0700 to 2300 
TABLE 1. Details of the seven ozone monitoring stations located in Delaware and reporting to the EPA's air quality system as of 2018 (DNREC-DAQ 2018). The station values that exceed the ozone standard are in boldface. Two additional monitoring stations, in Dover and Claymont, collected ozone data during 1982-94.

\begin{tabular}{|c|c|c|c|c|c|}
\hline AQS ID & Location & Lat $\left(^{\circ}\right)$ & Lon $\left(^{\circ}\right)$ & Since & Design value (ppm) \\
\hline $10-001-0002$ & Killens Pond & 38.98670 & -75.5568 & 1995 & 0.066 \\
\hline 10-003-1010 & Brandywine & 39.81722 & -75.5639 & 1994 & 0.074 \\
\hline $10-003-1013$ & Bellefonte & 39.77389 & -75.4965 & 1982 & 0.071 \\
\hline 10-003-2004 & Wilmington (MLK) & 39.73950 & -75.5575 & 2011 & 0.072 \\
\hline 10-003-1007 & Lums Pond & 39.55130 & -75.7320 & 1982 & 0.067 \\
\hline $10-005-1002$ & Seaford & 38.65390 & -75.6106 & 1983 & 0.065 \\
\hline $10-005-1003$ & Lewes & 38.77910 & -75.1632 & 1997 & 0.067 \\
\hline
\end{tabular}

LT (EPA 2015). The daily maximum 8-h average ozone value is used to calculate the so-called design value of each station, which is the $3-y r$ average of the annual fourth-highest daily maximum 8 -h average ozone concentration at each station. The National Ambient Air Quality Standard (NAAQS) for ozone is met when the design value is less than or equal to $0.070 \mathrm{ppm}$ and it is violated when the design value is greater than $0.070 \mathrm{ppm}$ (EPA 2015). In Delaware, three of the seven ozone monitoring stations were in violation of the NAAQS in 2018 (Table 1).

\section{b. NCEP-NCAR reanalyses}

Reanalysis data used for the synoptic typing come from the NCEP-NCAR reanalysis, version 1 (Kalnay et al. 1996). Reanalysis datasets are produced by assimilating various quality-controlled observations, including rawinsondes, surface marine data, aircraft data, surface land synoptic data, satellite sounder data, special sensing microwave imager, and satellite cloud drift winds, into a numerical weather prediction model (Parker 2016). The result is a gridded product that provides four-times daily "snapshots" of the atmosphere. The horizontal resolution of the NCEP-NCAR reanalysis products is about $2.5^{\circ}$ latitude $\times 2.5^{\circ}$ longitude. Here we use the variables sea level pressure (SLP), surface air temperature, $500-\mathrm{hPa}$ height, and precipitation rate. Data are available for the period from 1948 to the present, but again we focus on the period of 1986-2015.

\section{c. CMIP5 climate model data}

The CMIP5 archive contains model output from a plethora of models worldwide, run for dozens of experiments, as discussed in section 1 . Here we focus on the historical experiment simulations for the period 1986-2005 and the RCP8.5 scenario for 2006-15 (19862015 will be referred to as the "historical" period hereafter). Several different scenarios based on the radiative forcing by the end of the twenty-first century were used to generate projections of future climate in the CMIP5 project. The scenarios range from a low of
$2.6 \mathrm{~W} \mathrm{~m}^{-2}$ to a high of $8.5 \mathrm{~W} \mathrm{~m}^{-2}$. The RCP8.5 scenario explores a world in which population increases to 12 billion by 2100 along with income inequality. Meanwhile, limited technological advances mean that there is no concomitant increases in energy efficiency (Riahi et al. 2011). This scenario thus represents a "business as usual" trajectory for the future (van Vuuren et al. 2011; Taylor et al. 2012) that is realistic given the failure of countries to so far meet the goals of the Paris Agreement (Masson-Delmotte et al. 2018). Regardless of the choice of scenario, the sign of most changes in the future projections is consistent between the different scenarios, meaning if temperature increases in one scenario with more radiative forcing, it increases in another simulation with less radiative forcing, but to a lesser extent (Giorgi and Mearns 2002). Two future RCP8.5 10-yr periods are considered: the early (2025-34) and late (2045-54) midcentury. Both periods are close enough in time to be directly affected by policy decisions made today. In the early midcentury period, however, the underlying climate is not too different from today's, while the late midcentury period is likely to show stronger effects from global warming.

We used output from five different coupled atmosphereocean global circulation models in the CMIP5 archive (listed in Table 2) based on their performance over eastern North America, horizontal grid spacing, and availability of the relevant fields at daily and subdaily time scales. The horizontal grid spacing of the five models (degrees latitude by degrees longitude) is reported in Table 2. Pierce et al. (2009) have shown that using five models is sufficient to represent the behavior of the ensemble as a whole. Daily gridded data for the following variables were used for the analysis: SLP, surface air temperature, and precipitation. Because of Delaware's small size, all or most of the state is contained in a single grid cell of the CMIP5 models used, and thus the values for this single cell are used when local data are needed for temperature and precipitation. Additionally, the full gridded data for SLP over the eastern United States is used for spatial correlations with the NCEP reanalyses. 
TABLE 2. Details of the five selected CMIP5 models and trends (number of additional HO days yr ${ }^{-1}$ ) over the 30-yr historical period (1986-2015) and the 10-yr early (2025-34) and late (2045-54) midcentury periods.

\begin{tabular}{|c|c|c|c|c|c|}
\hline $\begin{array}{l}\text { Model abbreviation and } \\
\text { resolution }\left({ }^{\circ} \text { lat } \times{ }^{\circ} \text { lon }\right)\end{array}$ & Full model name & Institution and country & Historical & $\begin{array}{c}\text { Early } \\
\text { midcentury }\end{array}$ & $\begin{array}{l}\text { Late } \\
\text { midcentury }\end{array}$ \\
\hline HadGEM2 $\left(1.25^{\circ} \times 1.875^{\circ}\right)$ & $\begin{array}{l}\text { Hadley Centre Global } \\
\text { Environmental Model, } \\
\text { version } 2\end{array}$ & $\begin{array}{l}\text { Met Office Hadley Centre, } \\
\text { United Kingdom }\end{array}$ & 0.369 & 0.091 & 0.448 \\
\hline $\operatorname{MIROC5}\left(1.401^{\circ} \times 1.406^{\circ}\right)$ & $\begin{array}{l}\text { Model for Interdisciplinary } \\
\text { Research on Climate } \\
\text { (MIROC), version } 5\end{array}$ & MRI, Japan & 0.048 & 0.606 & -0.036 \\
\hline CCSM4 $\left(0.942^{\circ} \times 1.25^{\circ}\right)$ & $\begin{array}{l}\text { Community Climate System } \\
\text { Model (CCSM), version } 4\end{array}$ & $\begin{array}{l}\text { National Center for } \\
\text { Atmospheric Research } \\
\text { (NCAR), United States }\end{array}$ & 0.113 & 0.394 & 0.388 \\
\hline CNRM-CM5 $\left(1.401^{\circ} \times 1.406^{\circ}\right)$ & $\begin{array}{l}\text { Centre National de Recherches } \\
\text { Meteorologiques (CNRM) } \\
\text { Coupled Global Climate } \\
\text { Model, version } 5\end{array}$ & $\begin{array}{l}\text { CNRM Centre Européen } \\
\text { de Recherche et de } \\
\text { Formation Avancée en } \\
\text { Calcul Scientifique } \\
\text { (CERFACS), France }\end{array}$ & 0.180 & -0.521 & 0.430 \\
\hline $\operatorname{MRI}\left(1.122^{\circ} \times 1.125^{\circ}\right)$ & $\begin{array}{l}\text { Meteorological Research } \\
\text { Institute (MRI) Coupled } \\
\text { Atmosphere-Ocean General } \\
\text { Circulation Model, version } 3\end{array}$ & MRI, Japan & 0.040 & 0.588 & 0.321 \\
\hline Ensemble median & - & - & 0.225 & 0.230 & 0.582 \\
\hline
\end{tabular}

\section{Methods}

\section{a. High-ozone days from observations}

The NAAQS for ozone would be the most obvious choice to assess observed high-ozone days, but this metric has not been constant over the years. For example, the 8-h average standard for ozone was changed from $0.080 \mathrm{ppm}$ in 1997 (EPA 1997) to $0.075 \mathrm{ppm}$ in 2008 (EPA 2008) and then further reduced to $0.070 \mathrm{ppm}$ in 2015 (EPA 2015). In addition, the NAAQS for ozone is based on a rather complicated formula, including the calculation of the fourth-highest percentile each year and its average over three consecutive years (EPA 2015). Therefore, following the Air Quality Index (AQI; EPA 2017), a day is classified here as an HO day when the 8-h average ozone concentration at any station in Delaware exceeds the threshold of $70 \mathrm{ppb}$. In contrast to a large state, which would require multiple stations to identify observed high-ozone events, even just a single station is reasonable for a small state like Delaware.

Based on these criteria, we counted the frequency of observed HO events during the 30-yr observational record of ozone from 1986 to 2015. As shown in Fig. 2, the number of observed HO days decreased over the 30-yr period. For example, during the 1980s the average number of $\mathrm{HO}$ days was approximately 75 , whereas by 2015 it had decreased to less than 20. On average, each year during the study period had about 2 fewer days of high ozone per year (as the trend line in Fig. 2 has a slope of $-1.82 \mathrm{HO}$ days $\left.\mathrm{yr}^{-1}\right)$. This steady decline resulted from stricter regulations (such as federal and state air quality standards) and decreases in the emissions of ozone-forming pollutants.

\section{b. Synoptic typing}

Episodes of high ozone are associated with certain synoptic weather conditions, such as the passage of midlatitude cyclones and the western expansion of the Bermuda high (Shen et al. 2015). Because of climate change, the synoptic weather conditions conducive to high ozone concentrations may occur with greater frequency, therefore increasing the potential for more $\mathrm{HO}$ episodes.

The synoptic weather conditions present on any given day can be classified by the use of synoptic typing. Synoptic typing uses an assortment of meteorological variables, including temperature, humidity, sea level pressure, precipitation, cloud cover, and wind velocity, to investigate common trends in the synoptic conditions, in order to identify a limited number of types that explain the underlying synoptic-scale variability. The origins of these techniques can be traced to visual classifications by Lamb (1972) and computer-assisted statistical relationships of sea level pressure by Lund (1963).

The synoptic typing used in this study was originally developed in Siegert et al. (2017), using an eigenvectorbased approach (Kalkstein and Corrigan 1986; Yarnal 1993). Siegert et al. (2017) employed synoptic typing to assess hydroclimate in the mid-Atlantic states, with the same dataset expanded and used by Suriano and Leathers (2017) in evaluating lake-effect snowfall in the 


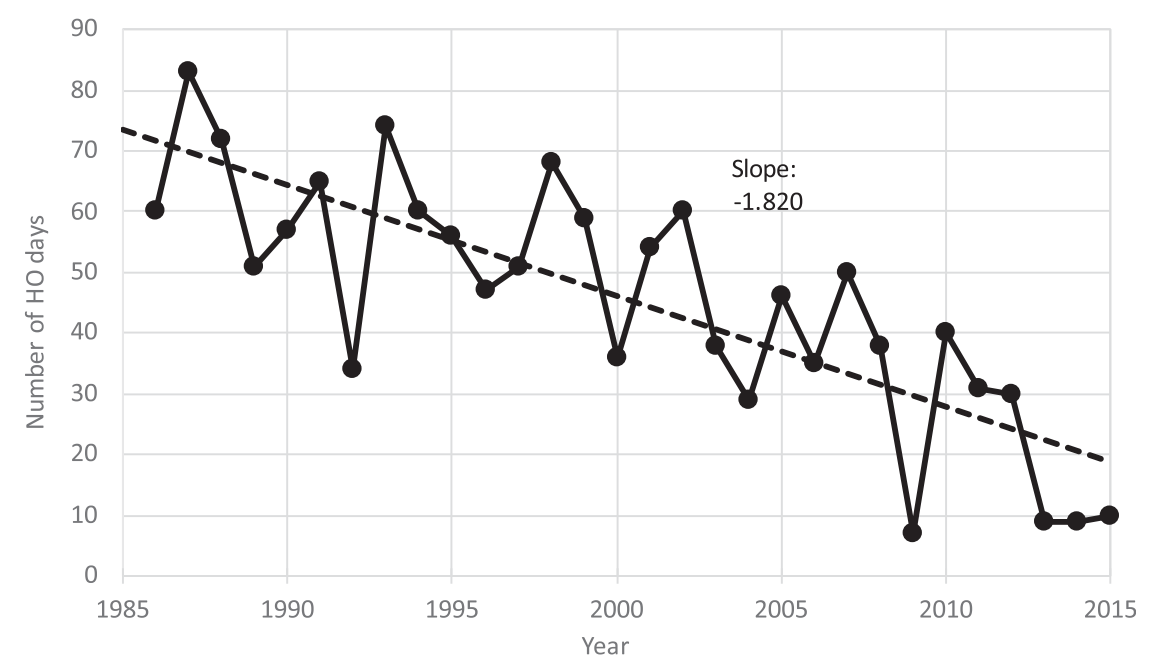

FIG. 2. Number of observed HO days per year from air quality monitoring sites in Delaware during the 30-yr period of 1986-2015.

Great Lakes region. Siegert et al. (2017) describe the procedure used to create the synoptic types as follows. Weather data from the period from 1948 to 2015 (temperature, dewpoint temperature, $u$ and $v$ wind components, atmospheric pressure, and cloud cover) taken four times daily $(0900,1500,2300,0300$ UTC) at the Philadelphia International Airport Station were input into an unrotated R-mode principal components analysis. They then identified the five principal components explaining at least $75 \%$ of the variance in the midAtlantic region of the United States (i.e., Pennsylvania, New Jersey, Maryland, and Delaware) for winter, spring, summer, and autumn. Within-group average linkage clustering analysis was used on the seasonal component loadings to produce clusters, or synoptic types. Initially 20 clusters were retained and composite maps were developed for each cluster representing SLP, 500-hPa geopotential height, surface air temperature, and surface precipitation rate using the NCEP-NCAR reanalysis (Kalnay et al. 1996). Because some of the clusters showed similar characteristics in the composite maps, they were combined based on expert assessment. This resulted in a variable number of synoptic types for each season: 12 in winter, 13 in spring, 9 in summer, and 11 in autumn. This research focuses on the nine synoptic types from the summer identified in Siegert et al. (2017), listed in Table 3, since the vast majority of high-ozone events in Delaware take place during the summer months.

Each summer day of the 30-yr record evaluated here (1986-2015) was assigned to one of the nine summer synoptic types, as defined by (Siegert et al. 2017), and to an ozone category ( $\mathrm{HO}$ or non-HO), as described in section 3a. In this way, the frequency distribution of synoptic types associated with $\mathrm{HO}$ days could be determined (Fig. 3). The nine types and their frequencies are shown in yellow in Fig. 3; the distribution of HO days by synoptic type is shown in blue.

The four most common synoptic types for the entire 30-yr period are southwesterly flow (SW), New England low (NELOW), overhead high (OHHI), and weak pattern (WEAK); the two synoptic types with the highest number of HO days are SW and NELOW (Table 3 ). Several synoptic types have spatial patterns that are highly correlated with each other, as shown in Table 4. The spatial pattern correlation $\rho_{A, B}$ between two SLP maps $A$ and $B$ representing either two synoptic types or an individual day's map and a synoptic type was calculated as follows:

TABLE 3. Summer synoptic types and their frequencies during the 30-yr historical period of 1986-2015 in terms of the number of days that each synoptic type occurred and the number of $\mathrm{HO}$ days within each synoptic type based on at least one observing station exceeding the 70-ppb threshold. In boldface are the synoptic types that will be later associated with $\mathrm{HO}$ days based on the climate models.

\begin{tabular}{|c|c|c|c|c|}
\hline \multirow[b]{2}{*}{ ID } & \multirow{2}{*}{$\begin{array}{l}\text { Original } \\
\text { ID }\end{array}$} & \multirow[b]{2}{*}{ Description } & \multicolumn{2}{|c|}{ Frequency } \\
\hline & & & All days & HO days \\
\hline HBLOW & 3006 & $\begin{array}{l}\text { Hudson Bay low, } \\
\text { frontal activity }\end{array}$ & 189 & 63 \\
\hline WEAKSW & 3010 & $\begin{array}{l}\text { Weak southwesterly } \\
\text { flow }\end{array}$ & 224 & 29 \\
\hline NEHI & 3013 & New England high & 70 & 0 \\
\hline NNW & 3020 & North-northwest flow & 62 & 15 \\
\hline OFFHI & 3031 & Offshore high & 247 & 54 \\
\hline WEAK & 3032 & Weak pattern & 305 & 68 \\
\hline NELOW & 3033 & New England low & 445 & 163 \\
\hline SW & 3034 & Southwest flow & 876 & 522 \\
\hline OHHI & 3035 & Overhead high & 310 & 99 \\
\hline
\end{tabular}




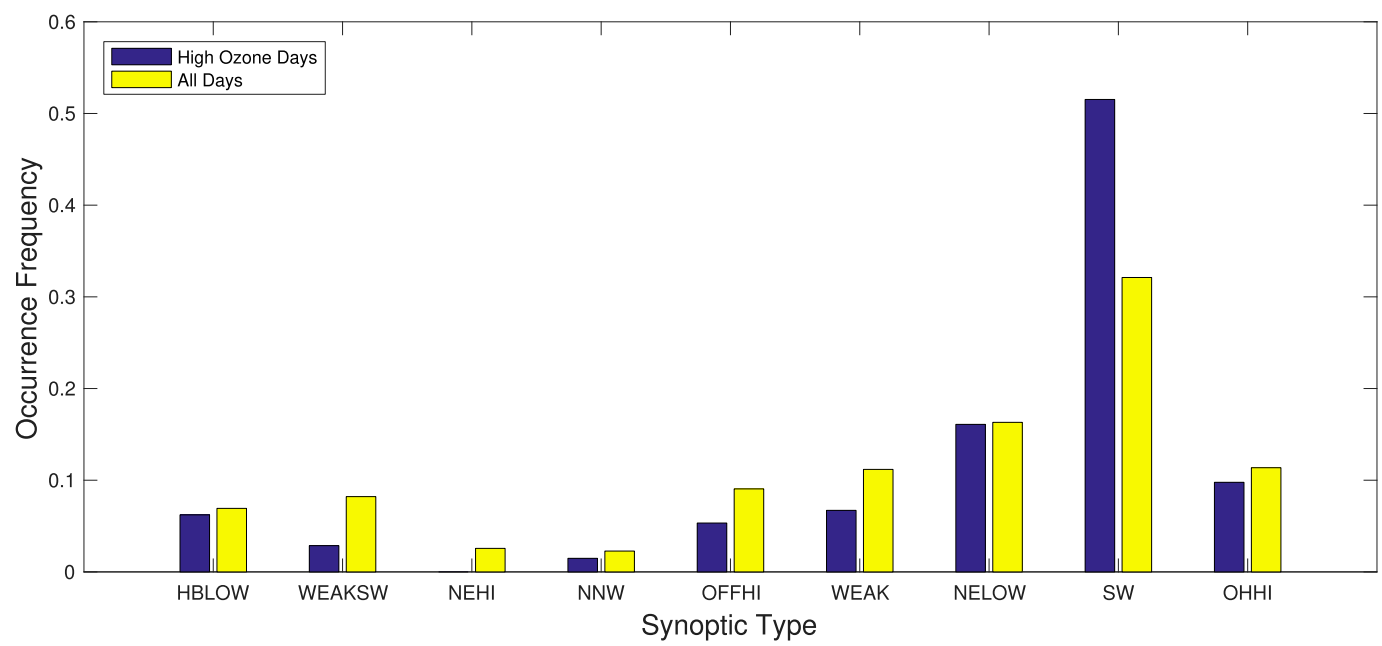

FIG. 3. Frequency distribution of observed (from NCEP-NCAR reanalyses) synoptic types during the summer season for the 30-yr study period of 1986-2015.

$$
\rho_{A, B}=\frac{\sum_{i=1}^{n}\left(A_{i}-\bar{A}\right)\left(B_{i}-\bar{B}\right)}{\sqrt{\sum_{i=1}^{n}\left(A_{i}-\bar{A}\right)^{2}} \sqrt{\sum_{i=1}^{n}\left(B_{i}-\bar{B}\right)^{2}}}
$$

where $\bar{A}$ and $\bar{B}$ represent the mean SLP for maps $A$ and $B$, respectively; $A_{i}$ and $B_{i}$ represent the SLP at grid point $i$ in maps $A$ and $B$, respectively; and $n$ represents the number of grid points. For example, both types HBLOW and WEAKSW are highly correlated (above 0.93 , Table 4) with type SW, since all share a generally southwesterly flow associated with the presence of the Bermuda high located around $30^{\circ} \mathrm{N}, 50^{\circ} \mathrm{W}$, which advects high temperatures and ozone precursors over the mid-Atlantic (Fig. 4). In contrast, the NELOW type is characterized by northwesterly flow that would advect precursors from the upper Midwest. The near-surface air temperature patterns between all four of these synoptic types are extremely similar (Fig. 5), with mean temperatures exceeding $25^{\circ} \mathrm{C}$ over the mid-Atlantic, except for the NELOW pattern, which has slightly lower temperatures. Additionally, many of the OHHI HO days occurred in the first decade (50 days in 198695 , not shown), and both the frequency of HO days that occurred during OHHI and the overall number of days of the OHHI synoptic types trended downward during the two subsequent decades (from 50 days in 1986-95 to 34 days in 1996-2005 to 15 days in 2006-15), reducing the influence of this type in more recent years. Therefore, we classified Hudson Bay low (HBLOW) and weak southwesterly flow (WEAKSW) as high-ozone types as well. Thus, our four HO synoptic types are: NELOW, SW, HBLOW, and WEAKSW.

\section{c. High-ozone days from the CMIP5 climate models}

Once the synoptic types associated with observed HO days have been determined, this information is used to classify which climate model days (historical and future simulations) have the potential to be HO days.

First, for each model day $t$ we calculated its spatial correlation $\rho_{t, j}$ with each of the nine summer synoptic

TABLE 4. Spatial pattern correlations between the summer synoptic types based on SLP. In boldface are the synoptic types that will be later associated with $\mathrm{HO}$ days based on the climate models.

\begin{tabular}{lccccccccc}
\hline Synoptic type & HBLOW & WEAKSW & NEHI & NNW & OFFHI & WEAK & NELOW & SW & OHHI \\
\hline HBLOW & 1 & 0.964 & 0.562 & 0.718 & 0.844 & 0.849 & 0.915 & 0.963 & 0.835 \\
WEAKSW & 0.964 & 1 & 0.672 & 0.656 & 0.860 & 0.914 & 0.872 & 0.934 & 0.827 \\
NEHI & 0.562 & 0.672 & 1 & 0.428 & 0.869 & 0.866 & 0.400 & 0.706 & 0.786 \\
NNW & 0.718 & 0.656 & 0.428 & 1 & 0.575 & 0.725 & 0.876 & 0.745 & 0.802 \\
OFFHI & 0.844 & 0.860 & 0.869 & 0.575 & 1 & 0.912 & 0.658 & 0.939 & 0.927 \\
WEAK & 0.849 & 0.914 & 0.866 & 0.725 & 0.912 & 1 & 0.781 & 0.912 & 0.931 \\
NELOW & 0.915 & 0.872 & 0.400 & 0.876 & 0.658 & 0.781 & 1 & 0.858 & 0.783 \\
SW & 0.963 & 0.934 & 0.706 & 0.745 & 0.939 & 0.912 & 0.858 & 1 & 0.938 \\
OHHI & 0.835 & 0.827 & 0.786 & 0.802 & 0.927 & 0.931 & 0.783 & 0.938 & 1 \\
\hline
\end{tabular}



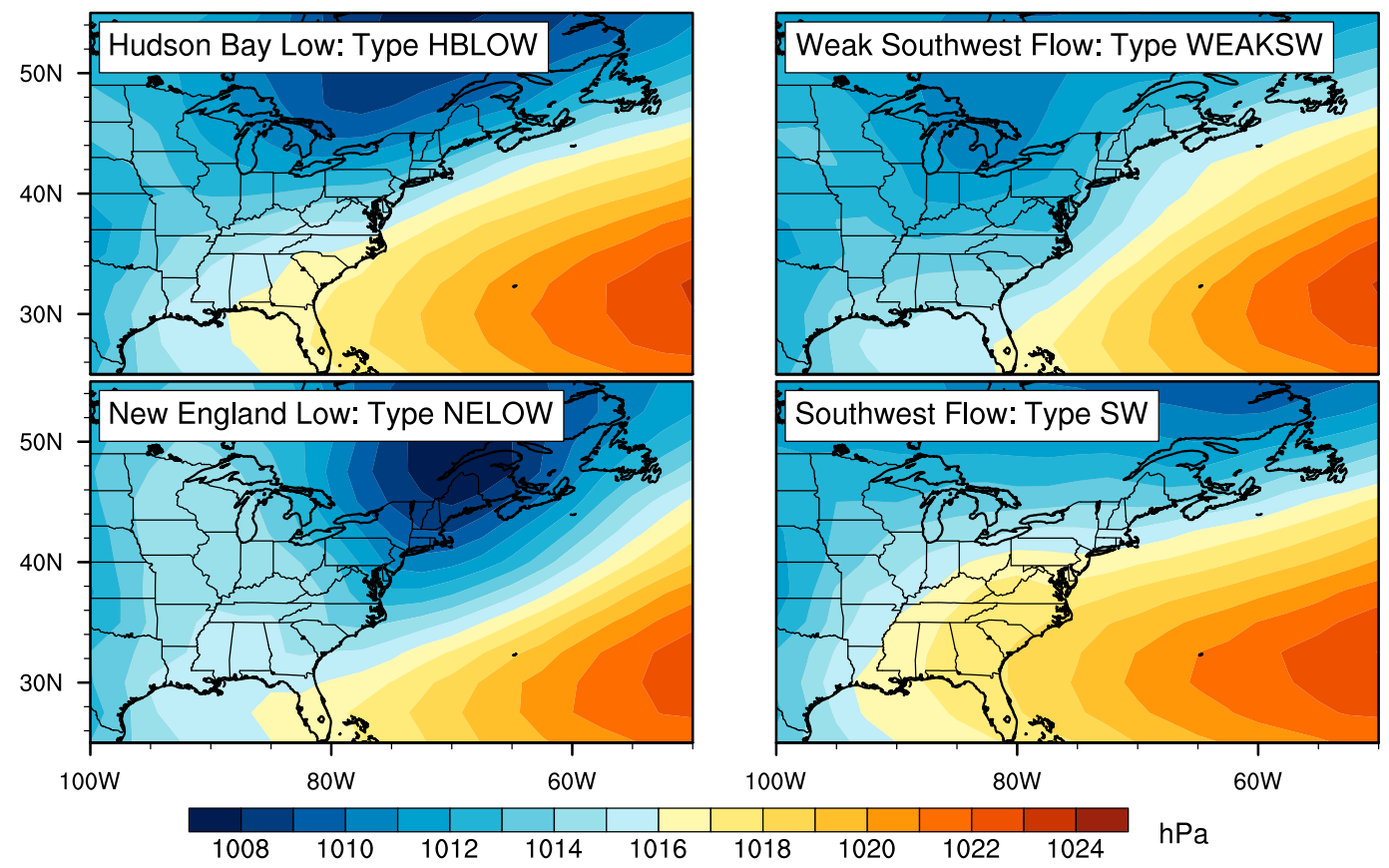

FIG. 4. Sea level pressure (hPa) composites from NCEP-NCAR reanalysis data for the four synoptic types used to evaluate $\mathrm{HO}$ days.

types using SLP [Eq. (1)]. The day $t$ was assigned the type $j$ that had the highest correlation, as long as it was greater than a minimum threshold of 0.5 . Furthermore, if the model day was classified as NELOW,
SW, HBLOW, or WEAKSW, then it was a possible HO day.

However, classifying a climate model day as one of the four HO synoptic types is necessary but not sufficient

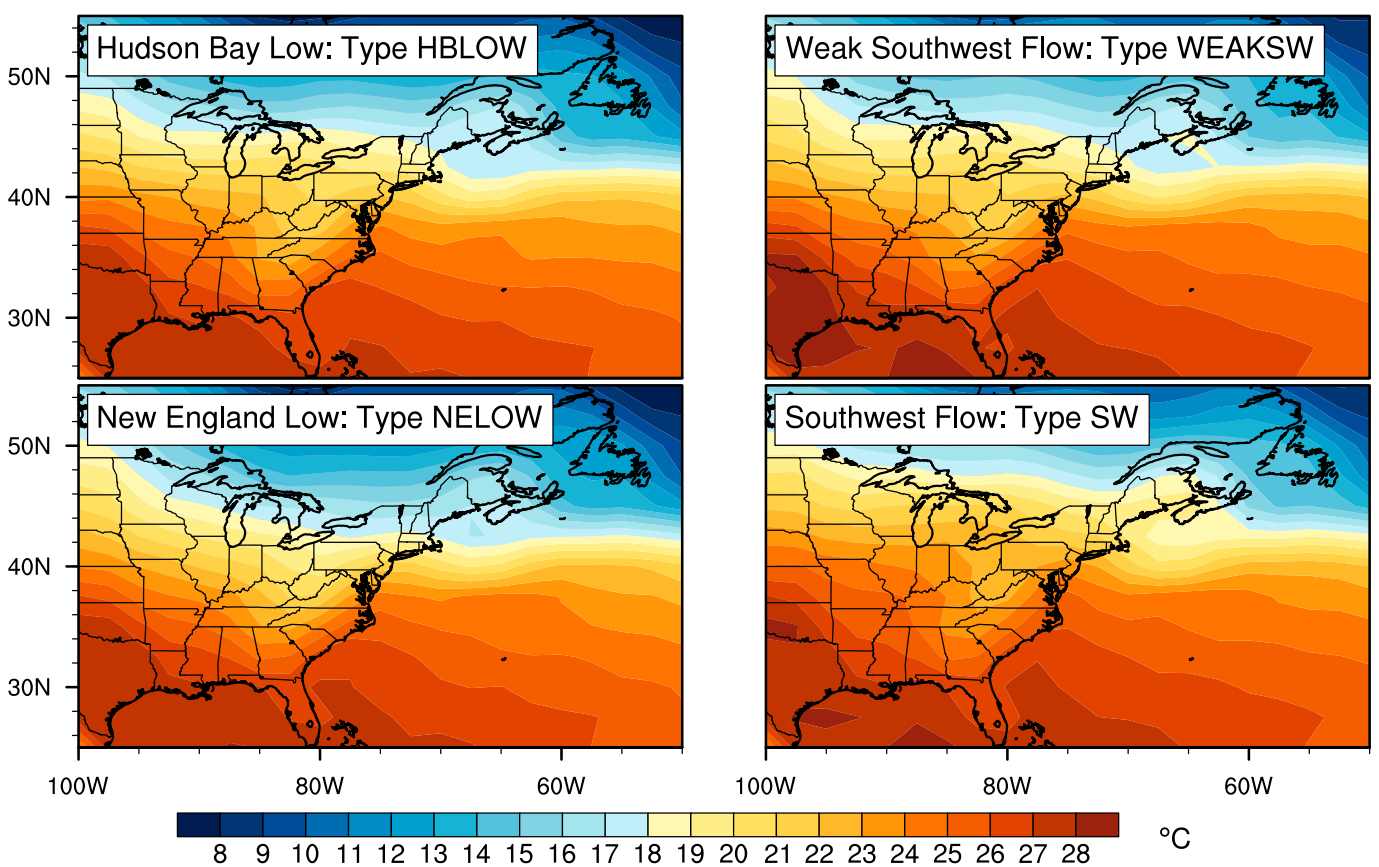

Fig. 5. Near-surface-temperature $\left({ }^{\circ} \mathrm{C}\right)$ composites from NCEP-NCAR reanalysis data for the four synoptic types used to evaluate $\mathrm{HO}$ days. 
for a $\mathrm{HO}$ day to occur. Based on our analysis of observed HO days in observations and reanalysis data, there are two additional conditions that must be met for a highozone day to occur.

First, high temperatures are required within those four $\mathrm{HO}$ synoptic types. We determined that $90 \%$ of the $\mathrm{HO}$ events that occurred during synoptic type SW (the warmest type) had a daily mean temperature of $25.5^{\circ} \mathrm{C}$ or higher. Although the other three HO synoptic types had lower temperature thresholds, we selected $25.5^{\circ} \mathrm{C}$ in order to capture the more "extreme" cases of the other three types and to minimize the probability of false $\mathrm{HO}$ days. Note that this threshold is for the mean daily temperature; the daily highest temperature on $\mathrm{HO}$ days consistently exceeded $32^{\circ} \mathrm{C}\left(90^{\circ} \mathrm{F}\right)$, but mean temperature is used since that variable is more readily available in the CMIP5 archive. Also, the choice of $25.5^{\circ} \mathrm{C}$ allowed us to better capture the observed distribution of $\mathrm{HO}$ days over the four synoptic types during the last decade (2006-15). Since ultimately we want to compare future climate to the present, it is more reasonable to calibrate our criteria based on the last decade of the historical period.

Second, only days when there was no measurable precipitation in the models (defined as less than $1 \mathrm{~mm} \mathrm{day}^{-1}$ ) were considered to be favorable to high ozone. Precipitation prevents ozone formation because of both reduction of sunlight, which drives the photochemical reactions, and washout of the available precursor pollutants.

In summary, any model day that met all three criteria (HO synoptic type, mean daily temperature above $25.5^{\circ} \mathrm{C}$, and precipitation below $1 \mathrm{~mm} \mathrm{day}^{-1}$ ) was classified as an HO day.

\section{Results}

This section describes the results of the application of the three criteria described previously in section $3 \mathrm{c}$ to the five selected CMIP5 models, for the 30-yr historical record (1986-2015) and two future decades: 2025-34 and 2045-54. Before presenting the results, we would like to point out a few important properties of climate simulations that will help interpreting the findings of this study.

First, we do not expect an HO day in the model to exactly match an $\mathrm{HO}$ day in the real world. Weather evolves in a climate model the same way as it does in the real world, but not on a day-to-day or year-to-year basis. For example, if temperature was above $35^{\circ} \mathrm{C}$ on 1 September 2015 , it is not expected to be above $35^{\circ} \mathrm{C}$ on the same day or year in the climate model. Rather, the climate model should have the same frequency of days above $35^{\circ} \mathrm{C}$ as the real world over the course of a decade.
With respect to ozone, climate models are not expected to perfectly capture the number of HO days year by year, but rather the characteristics of the underlying variability and frequency over time scales of a decade or longer. In other words, the model results show how the number of HO days would have changed over the past 30 years if the regulatory and societal factors were held constant at 2015 levels (i.e., a standard of $70 \mathrm{ppb}$ for 8-h average ozone, along with 2015 emission standards and industry pollution controls). This allows the climate models to provide estimates of how the number of $\mathrm{HO}$ days would fluctuate solely because of the climate, and not to societal and regulatory changes.

Second, since climate models do not account for changes in regulations or emissions that impact air pollution but do account for the positive correlation between ozone and temperature, the historical climate simulations will show increasing ozone days because of warming (as discussed shortly in section $4 \mathrm{a}$ ), while observations previously indicated decreasing $\mathrm{HO}$ days because of air quality protection legislation and emission regulations (section 3a). Nonetheless, there is still value in analyzing trends in climate models over the historical period because 1) they explain how HO frequency is impacted by climate change alone and 2) they provide a baseline for comparison against future projections of HO days.

\section{a. Trends in high-ozone days from the CMIP5 climate models}

The selected CMIP5 models were first evaluated for the 30-yr historical period from 1986 to 2015. This allows for assessment of the performance of the detection algorithm for a period of time for which ozone observation data were readily available. Recall that we calibrated our ozone day detection algorithm using the period 2006-15 (section 3c). Using this decade, we see that the average number of ozone days is about $16 \mathrm{yr}^{-1}$ by 2015 (Fig. 6a), which slightly underestimates the observed number of days by three according to the trend line in Fig. 2. The most noticeable feature in Fig. $6 a$ is that the number of HO days simulated by the CMIP5 models increases, which may appear to contradict the observations shown in Fig. 2. However, regulations introduced during the $30-\mathrm{yr}$ period, accompanied by advances in emissions reducing technologies (e.g., improved automobile fuel economy), resulted in a decline in HO days. The effects of these changes are not included in climate models. Therefore, the models show increasing HO days because of the higher temperatures simulated in response to elevated greenhouse gases. Effectively, the models show an approximation of the number of $\mathrm{HO}$ days that would have been expected earlier in the time 

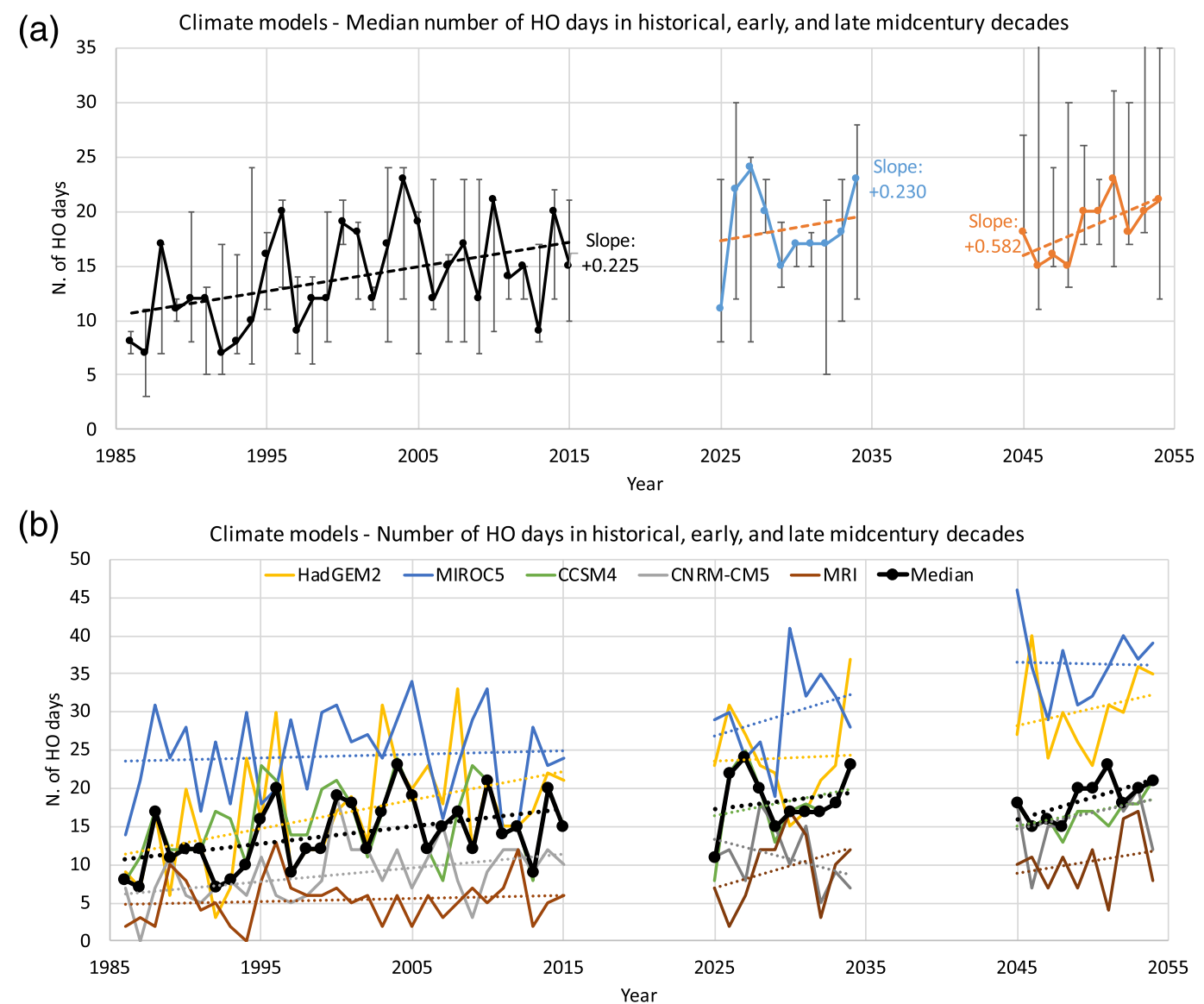

FIG. 6. Number of HO days predicted by the five CMIP5 climate models during the 30-yr historical period (19862015), the early midcentury (2025-34), and the late midcentury (2045-54). (a) The median of the five models is shown with error bars corresponding to the first and third quartiles; the trend lines are drawn with dashes and their slopes (HO days $\mathrm{yr}^{-1}$ ) are indicated. (b) The individual models are shown with thin colored lines, the median of the five models with a thick black line, and the trends with dotted lines.

period if emissions standards were consistent over the full 30-yr period. The models that simulate the highest number of HO days are the HadGEM2 and MIROC5 models, with between 20 and 23 HO days (Fig. 6b). All the models show a positive trend over 1986-2015, although the values vary from +0.04 to $+0.37 \mathrm{HO}$ days $\mathrm{yr}^{-1}$. The slope of the model median over the entire 30 -yr period is $+0.225 \mathrm{HO}$ days $\mathrm{yr}^{-1}$, which means that it takes about 5 years to add another $\mathrm{HO}$ day per year. Since the criteria were tuned to the most recent decade (2006-15), the model results match the observations very well during those 10 years, but underestimate the number of $\mathrm{HO}$ days in the two earlier decades.

Next we look at two future decades (2025-34 and 2045-54) in Figs. 6. The slope of the median during the early midcentury is similar to the historical period $\left(+0.230 \mathrm{HO}\right.$ days $\left.\mathrm{yr}^{-1}\right)$. Therefore, it takes about four years to increase the number of $\mathrm{HO}$ days by one. However, the trend accelerates during the late midcentury, increasing to $+0.582 \mathrm{HO}$ days $\mathrm{yr}^{-1}$, corresponding to an additional ozone day every 2 years. The variability does not change between the three periods, as the coefficient of variation is approximately the same $(0.53,0.52,0.51$, respectively, for 2006-15, 2025-34, and 2045-54).

All models show an increase in the number of $\mathrm{HO}$ days in the two midcentury periods compared to the historical period (Fig. 6b). There is a fairly wide spread in the number of $\mathrm{HO}$ days projected by the models with a range of 10-35 HO days by 2055 . The Meteorological Research Institute (MRI) model projects the lowest number of $\mathrm{HO}$ days in all three periods, although notably the number of $\mathrm{HO}$ days increases in the later two periods. MIROC5 shows consistently high numbers of $\mathrm{HO}$ days in all three periods, with $25 \mathrm{HO}$ days in the historical period and $40 \mathrm{HO}$ days by the end of 2055 . CCSM4 is similar to the model median for all periods. Some models show variability between the two midcentury periods, with more HO days during 2025-35 


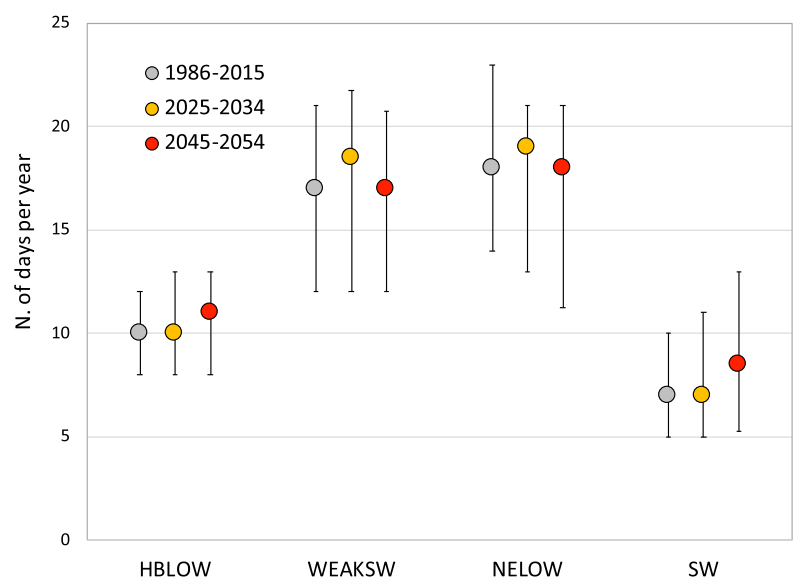

FIG. 7. Median frequency (days $\mathrm{yr}^{-1}$ ) of the four HO synoptic types (HBLOW, WEAKSW, NELOW, and SW) from the five CMIP5 climate models during the historical (1986-2015; gray), early midcentury (2025-34; yellow), and late midcentury (2045-54; red) periods. The error bars represent the quartiles.

than during 2045-55. This is not unexpected because of the use of two fairly short periods in the midcentury, since the different representative concentration pathways do not diverge until the midcentury (IPCC 2013) and the radiative forcing remains below $5 \mathrm{~W} \mathrm{~m}^{-2}$.

\section{b. Climatic factors driving high-ozone-day changes}

The increases in $\mathrm{HO}$ days projected by the models may be the result of three factors: an increase in the frequency of synoptic types conducive to $\mathrm{HO}$ days (i.e., the four HO synoptic types SW, NELOW, HBLOW, and WEAKSW); an increase in daily mean temperature; and a decrease in the number of days with precipitation.
Starting with the synoptic types first, Fig. 7 shows the median predictions of number of days in each of the four HO synoptic types (without using the temperature or precipitation criteria). For two of the types (WEAKSW and NELOW), the frequency does not change substantially between the three periods, although it never decreases from the historical to the late midcentury period. However, there is a noticeable increase in the number of

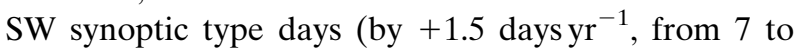
8.5 days $^{-1}$ ) in 2045-54 relative to the historical period. Also synoptic type HBLOW is projected to occur with higher frequency in 2045-54 than in the historical

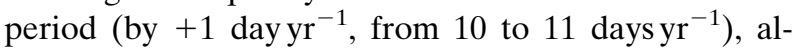
though less significantly that the SW type.

The increase in the number of SW and HBLOW synoptic type events $\left(+1.5\right.$ and +1 days $\mathrm{yr}^{-1}$, respectively, for a total of $+2.5{\text { days } \mathrm{yr}^{-1}}^{-1}$ ) is smaller than the overall increase in $\mathrm{HO}$ days $\left(+5\right.$ days $\mathrm{yr}^{-1}$, Fig. 6$)$. Because $\mathrm{HO}$ days in the model simulations must be one of these four synoptic types (i.e., changes in other synoptic types are not considered), increases in temperature or increases in the frequency of dry days (or decreases in the frequency of days with precipitation) must be contributing to the increase in $\mathrm{HO}$ days. To evaluate this, we examined what changes the models showed over the summer months in the average daily mean temperature and in the number of dry days predicted. Overall, the models did not show any statistically significant trends in the number of dry days (not shown). However, the models did predict an increase in the average daily mean temperature (Fig. 8); the overall model mean increased from $24^{\circ} \mathrm{C}$ in 1986 to nearly $27^{\circ} \mathrm{C}$ in 2054 , a change in mean summer temperature of $+0.38^{\circ} \mathrm{C}$ decade $^{-1}$. By the

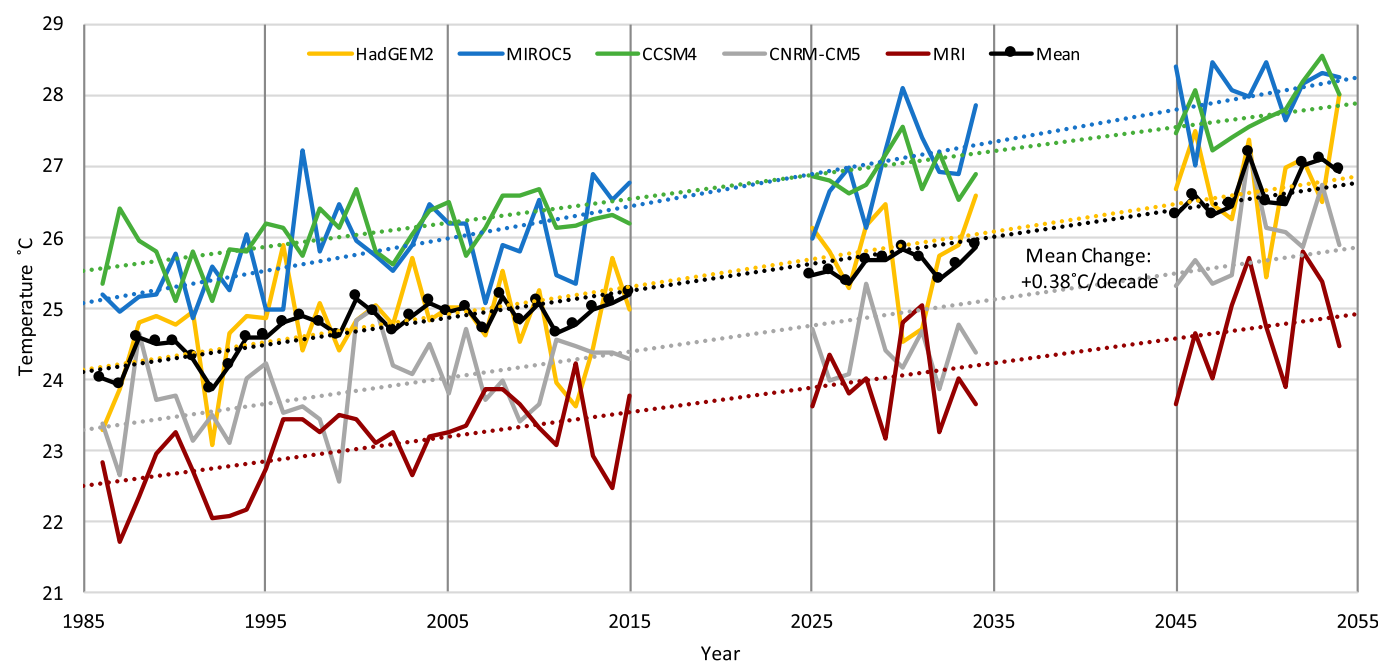

FIG. 8. Change in mean daily temperature over Delaware during the summer season for the five CMIP5 climate models, along with the model-mean temperature. 
decade 2045-54, in fact, the five-model daily mean temperature exceeded the $25.5^{\circ} \mathrm{C}$ threshold that we adopted for HO days every year. Furthermore, it can be seen in Fig. 8 that the model with the lowest mean summer temperature, MRI, also predicted the fewest $\mathrm{HO}$ days (Fig. 6b), while one of the warmest climate models, MIROC5, also predicted the most HO days. This confirms qualitatively the importance of underlying temperature changes, not only synoptic type frequency changes, to the projected increases in the number of $\mathrm{HO}$ days by midcentury.

\section{Discussion and conclusions}

In this study, we examined climate model projections for the mid-twenty-first century to determine how the number of days with ozone levels high enough to be unhealthy for sensitive populations- $-\mathrm{HO}$ days-may change over the mid-Atlantic. We used a two-step approach. First we identified the atmospheric circulation patterns ("synoptic types") that were most likely to occur during observed HO days in the past. Four synoptic patterns are associated with high-ozone days over the mid-Atlantic: New England low (NELOW), southwesterly flow (SW), weak southwesterly flow (WEAKSW), and Hudson Bay low (HBLOW). Second, we imposed two other criteria: no precipitation and high daily mean temperatures (exceeding $25.5^{\circ} \mathrm{C}$ ).

Next we applied the three criteria above to five selected CMIP5 models (HadGEM2, MIROC5, CCSM4, CNRM-CM5, and MRI) to calculate the frequency of $\mathrm{HO}$ days in the future. Before looking at the RCP8.5 midcentury projections, however, we prepared model predictions for the historical period of 1986-2015, to establish a baseline for comparison. Midcentury projections from the five CMIP5 models show that HO days are expected to increase, from about one extra HO day every 5 years to 1 extra HO day every 2 years. This is due to an increase in the frequency of $\mathrm{HO}$ synoptic types (in particular, the dominant SW type associated with southwesterly flow) and to increases in temperature, without noticeable changes in the frequency of dry days.

Historically, the number of high-ozone days in Delaware decreased by 2 days every year because of stricter air quality regulations, despite the underlying increases in temperature due to increasing greenhouse gases. Our results indicate that this progress will be partially negated as temperatures continue to increase and southwesterly-flow synoptic types become more frequent. Therefore, maintaining current ozone levels will require even stricter regulations than currently exist. Our study focused on the frequency of $\mathrm{HO}$ days. However, the ozone concentration during HO days itself may also increase (i.e., more intense $\mathrm{HO}$ days).

Future work should focus on quantifying these potential changes and their direct health impacts. In addition, other synoptic types, not currently associated with HO days, may become HO types in the future; some synoptic types may disappear; and entirely new HO synoptic types may manifest themselves. Thus we may be underestimating the changes in future HO days. Future studies should also examine spring and fall, as these transition seasons are expected to become warmer in the future, and look for potential changes in the duration of $\mathrm{HO}$ events.

Acknowledgments. This research was sponsored by the Delaware Department of Natural Resources and Environmental Control (DNREC), Division of Energy and Climate (DEC) and Division of Air Quality (DAQ), Grant 16A01486. In particular, the authors would like to acknowledge the support of Ali Mirzakhalili, former Director of DAQ at DNREC. The authors would also like to thank Daniel Leathers and Zachary Suriano for providing synoptic typing data. We thank Emily Aiken, who assisted with downloading CMIP5 data. NCEP reanalysis data were provided by the NOAA/OAR/ESRL PSD, Boulder, Colorado, and are available from their website at http://www.esrl.noaa.gov/psd/. This research was conducted in part on the Mills and Farber highperformance computer clusters of the University of Delaware.

\section{REFERENCES}

Anderson, B. G., and M. L. Bell, 2009: Weather-related mortality: How heat, cold, and heat waves affect mortality in the United States. Epidemiology, 20, 205-213, https://doi.org/10.1097/ EDE.0b013e318190ee08.

Curriero, F. C., K. S. Heiner, J. M. Samet, S. L. Zeger, L. Strug, and J. A. Patz, 2002: Temperature and mortality in 11 cities of the eastern United States. Amer. J. Epidemiol., 155, 80-87, https:// doi.org/10.1093/aje/155.1.80.

DNREC-DAQ, 2016: Delaware annual air quality report 2016. Delaware Natural Resources and Environmental Control, Division of Air Quality, accessed 16 August 2018, http:// www.dnrec.delaware.gov/Air/Documents/Ann \%20Rpt\% 2016\%20final.pdf.

__, 2018: 2018 Delaware ambient air monitoring network description for criteria pollutants. Delaware Natural Resources and Environmental Control, Division of Air Quality, accessed 16 August 2018, http://www.dnrec.delaware.gov/Air/Documents/ DE\%20mon\%20net\%20desc\%202018.pdf.

EPA, 1997: National ambient air quality standards for ozone. Federal Register, Vol. 62, National Archives and Records Administration, 38 856-38 896, https://www.gpo.gov/fdsys/ pkg/FR-1997-07-18/pdf/97-18580.pdf.

, 2008: National ambient air quality standards for ozone. Federal Register, Vol. 73, National Archives and Records 
Administration, 16 436-16 514, https://www.gpo.gov/fdsys/ pkg/FR-2008-03-27/pdf/E8-5645.pdf.

, 2015: National ambient air quality standards for ozone. Federal Register, Vol. 80, National Archives and Records Administration, 65 292-65 468, https://www.epa.gov/ozone-pollution/ 2015-national-ambient-air-quality-standards-naaqs-ozone.

__ 2017: Air Quality Index (AQI) basics. Accessed 17 February 2017, https://www.airnow.gov/index.cfm?action=aqibasics.aqi.

_ 2018a: Air data: Air quality data collected at outdoor monitors across the U.S. Accessed 16 August 2018, https:// www.epa.gov/outdoor-air-quality-data.

_ 2018 b: Basic information about ozone. Accessed 16 August 2018, https://www.epa.gov/ozone-pollution/basic-informationabout-ozone\# effects.

Giorgi, F., and L. O. Mearns, 2002: Calculation of average, uncertainty range, and reliability of regional climate changes from AOGCM simulations via the "reliability ensemble averaging" (REA) method. J. Climate, 15, 1141-1158, https://doi.org/ 10.1175/1520-0442(2002)015<1141:COAURA > 2.0.CO;2.

IPCC, 2013: Climate Change 2013: The Physical Science Basis. Cambridge University Press, 1535 pp., https://doi.org/10.1017/ CBO9781107415324.

Kalkstein, L. S., and P. Corrigan, 1986: A synoptic climatological approach for geographical analysis: Assessment of sulfur dioxide concentrations. Ann. Assoc. Amer. Geogr., 76, 381-395, https://doi.org/10.1111/j.1467-8306.1986.tb00126.x.

Kalnay, E., and Coauthors, 1996: The NCEP/NCAR 40-Year Reanalysis Project. Bull. Amer. Meteor. Soc., 77, 437-471, https:// doi.org/10.1175/1520-0477(1996)077<0437:TNYRP>2.0.CO;2.

Lamb, H. H., 1972: British Isles weather types and a register of daily sequence of circulation patterns, 1861-1971. Geophysical Memoir, Vol. 116, H.M. Stationery Office, 85 pp.

Leibensperger, E. M., L. J. Mickley, and D. J. Jacob, 2008: Sensitivity of us air quality to mid-latitude cyclone frequency and implications of 1980-2006 climate change. Atmos. Chem. Phys., 8, 7075-7086, https://doi.org/10.5194/acp-8-7075-2008.

Lund, I. A., 1963: Map-pattern classification by statistical methods. J. Appl. Meteor., 2, 56-65, https://doi.org/10.1175/15200450(1963)002<0056:MPCBSM > 2.0.CO;2.

Maloney, E. D., and Coauthors, 2014: North American climate in CMIP5 experiments: Part III: Assessment of twenty-firstcentury projections. J. Climate, 27, 2230-2270, https://doi.org/ 10.1175/JCLI-D-13-00273.1.
Masson-Delmotte, V., and Coauthors, Eds., 2018: Global Warming of $1.5^{\circ} \mathrm{C}$. World Meteorological Organization, $562 \mathrm{pp}$.

Melillo, J. M., T. C. Richmond, and G. W. Yohe, 2014: Climate Change Impacts in the United States: The Third National Climate Assessment. U.S. Government Printing Office, 841 pp., https://doi.org/10.7930/J0Z31WJ2.

Moghani, M., C. L. Archer, and A. Mirzakhalili, 2018: The importance of transport to ozone pollution in the U.S. MidAtlantic. Atmos. Environ., 191, 420-431, https://doi.org/10.1016/ j.atmosenv.2018.08.005.

Monks, P., and Coauthors, 2015: Tropospheric ozone and its precursors from the urban to the global scale from air quality to short-lived climate forcer. Atmos. Chem. Phys., 15, 8889-8973, https://doi.org/10.5194/acp-15-8889-2015.

Parker, W. S., 2016: Reanalyses and observations: What is the difference? Bull. Amer. Meteor. Soc., 97, 1565-1572, https:// doi.org/10.1175/BAMS-D-14-00226.1.

Pierce, D. W., T. P. Barnett, B. D. Santer, and P. J. Gleckler, 2009: Selecting global climate models for regional climate change studies. Proc. Natl. Acad. Sci. USA, 106, 8441-8446, https:// doi.org/10.1073/pnas.0900094106.

Riahi, K., and Coauthors, 2011: RCP 8.5-A scenario of comparatively high greenhouse gas emissions. Climatic Change, 109, 33, https://doi.org/10.1007/s10584-011-0149-y.

Shen, L., L. J. Mickley, and A. P. K. Tai, 2015: Influence of synoptic patterns on surface ozone variability over the eastern United States from 1980 to 2012. Atmos. Chem. Phys., 15, 10925 10 938, https://doi.org/10.5194/acp-15-10925-2015.

Siegert, C. M., D. J. Leathers, and D. F. Levia, 2017: Synoptic typing: Interdisciplinary application methods with three practical hydroclimatological examples. Theor. Appl. Climatol., 128, 603-621, https://doi.org/10.1007/s00704-015-1700-y.

Suriano, Z. J., and D. J. Leathers, 2017: Synoptic climatology of lakeeffect snowfall conditions in the eastern Great Lakes region. Int. J. Climatol., 37, 4377-4389, https://doi.org/10.1002/joc.5093.

Taylor, K. E., R. J. Stouffer, and G. A. Meehl, 2012: An overview of CMIP5 and the experiment design. Bull. Amer. Meteor. Soc., 93, 485-498, https://doi.org/10.1175/BAMS-D-11-00094.1.

van Vuuren, D. P., and Coauthors, 2011: The representative concentration pathways: an overview. Climatic Change, 109, 5-31, https://doi.org/10.1007/s10584-011-0148-z.

Yarnal, B., 1993: Synoptic Climatology in Environmental Analysis: A Primer. Belhaven Press, 195 pp. 